\title{
Effects of citicoline and atorvastatin administration on the regenerative capacity of the distal segment of the transected sciatic nerve in conditions of delayed nerve repair
}

\section{Samira Bolandghamat}

Ferdowsi University of Mashhad

Morteza Behnam-Rassouli ( $\square$ Behnam.rassouli1@gmail.com )

Ferdowsi University of Mashhad

Nasser Mahdavi-Shahri

Ferdowsi University of Mashhad

Ali Moghimi

Ferdowsi University of Mashhad

\section{Research Article}

Keywords: Nerve repair, Delayed nerve repair, Sciatic nerve, Citicoline, Atorvastatin

Posted Date: February 23rd, 2022

DOI: https://doi.org/10.21203/rs.3.rs-1370749/v1

License: (c) (1) This work is licensed under a Creative Commons Attribution 4.0 International License.

Read Full License 


\section{Abstract}

Background》 Pharmacotherapy is a cheap, accessible and non-invasive treatment that can be used in the first hours after the nerve injury. Although using some drugs after nerve injury accelerates the nerve repair process. But their functional outcomes are still not satisfactory. Therefore, the aim of the present study was to evaluate the effects of citicoline and atorvastatin administration on maintaining the regenerative capacity of the distal segment of the transected sciatic nerve in conditions of delayed nerve repair

Methods $\rrbracket$ The sciatic nerve of rats was transected and the animals were interaperitoneally administrated citicoline $(200 \mathrm{mg} / \mathrm{kg})$, atorvastatin $(5 \mathrm{mg} / \mathrm{kg})$, citicoline + atorvastatin and vehicles (control groups) for one month. In the sham group, the sciatic nerve was only exposed. After one month, the transected nerve was repaired by nerve allograft. Fourteen weeks after surgical repair, morphometric and electron microscopic evaluations were performed on the nerve.

Results $\$ The morphometric and ultrastractural indices of the distal nerve segment were improved in the citicoline, atorvastatin and citicoline + atorvastatin groups compared to that of control groups $(P<0.01)$. It seems that the co-administration of citicoline and atorvastatin, has a synergistic effect on the nerve repair.

Conclusions $\mathbb{X}$ The results of this study show that, in the situations that immediate nerve repair using surgery is not possible, administration of citicoline, atorvastatin or a combination of both drugs can keep the regenerative capacity of the distal segment of the transected nerve.

\section{Introduction}

Rodent models of peripheral nerve injury (PNI) have improved our insights into the biological mechanisms of peripheral nerve regeneration, but clinical applications of these models have been rare, partly because such models do not adequately recapitulate human nerve injuries [1]. Unlike the mouse models of $\mathrm{PNI}$, in humans, immediate surgical nerve repair is not possible due to inflammation, the patient's general condition, or performing diagnostic tests [2]. Moreover, in human nerve injuries, axons often regenerate for longer distances than those of mice, and injury leaves distal nerve fibers and target tissues without axonal contact for extended amounts of time [1]. Following chronic denervation, distal Schwann cells undergo atrophy that is accompanied by reduced expression of neurotrophic factors, changes in the extracellular matrix and loss of Schwann cell basal lamina, which all prevent axonal regeneration [1]. Furthermore, atrophy and other denervation-induced changes in target tissues cause poor functional recovery even when axons regenerate all the way to the target tissue [1]. To improve functional outcomes in humans, strategies to increase the speed of axonal growth, maintain Schwann cells in a healthy, repair-capable state and keep target tissues receptive to reinnervation are needed [1]. Therefore, animal models of delayed nerve repair are more similar to human models of nerve repair [3]. On the other hand, poor functional recovery after delayed nerve repair highlights the need for pharmacological interventions. Citicoline is an intracellular precursor of the phosphatidylcholine [4], and 
the atorvastatin is a member of the statin family [5]. Both medications exert anti-inflammatory, antioxidative and anti-apoptotic effects in CNS disorders [4,5]. Moreover, the previous studies have shown the beneficial effects of citicoline and atorvastatin in the models of the immediate surgical repair of the injured nerve [6-11]. However, their efficacy in a delayed nerve repair model has not been examined yet. This study was aimed to investigate the effects of citicoline and atorvastatin on the delayed nerve regeneration of the rat sciatic nerve.

\section{Materials And Methods}

\section{Animals}

The study was conducted on 45 adult male Wistar rats (250-300 g). Animals were housed under standard room conditions with free access to food and water. All experiments carried out in accordance with the National Institutes of Health guide for the care and use of Laboratory animals (NIH Publications No. 8023, revised 1978). The experimental protocol was approved by the National Committee for Ethics in Biomedical Research (approval ID: IR.UM.REC.1398.090). The rats randomly divided into six groups: citicoline group ( $\mathrm{n}=8) ; 200 \mathrm{mg} / \mathrm{kg}$ citicoline (Alborz Daru Co., Iran) [12] was dissolved in saline and intraperitoneally administered at the end of nerve transection surgery and continued for one month. Atorvastatin group ( $\mathrm{n}=8) ; 5 \mathrm{mg} / \mathrm{kg}$ atorvastatin (Poursina Co., Iran) [11] was dissolved in DMSO: saline: Tween $80(1: 94: 5, \mathrm{v} / \mathrm{v})$ and intraperitoneally administered for one month after nerve transection. Citicoline + atorvastatin group $(\mathrm{n}=8)$; The simultaneous treatment with citicoline and atorvastatin was administered for one month after nerve transection. Control group $1(n=8)$; the saline was administered for one month after nerve transection. Control group $2(n=8)$; DMSO: saline: Tween $80(1: 94: 5, v / v)$ was intraperitoneally administered for one month after nerve transection and sham group $(n=5)$; the right sciatic nerve was only exposed.

\section{Surgical procedures}

All surgical procedures were conducted under aseptic conditions. After anesthetizing the animals (50 $\mathrm{mg} / \mathrm{kg}$ ketamine hydrochloride and $5 \mathrm{mg} / \mathrm{kg}$ xylazine, Alfasan, Holland), the right sciatic nerves of the rats were exposed and transected at the mid-thigh using a surgical blade. To prevent nerve regeneration, each nerve ending was epineurally sutured to itself in a loop-like shape, using 8-0 nylon suture. The incision was closed in the layers with 4-0 silk suture [13]. For prophylaxis, animals were received subcutaneous injections of $30 \mathrm{mg} / \mathrm{kg}$ cefazoline [14], half an hour before surgery, and then 24 and $48 \mathrm{~h}$ later. After one month, the transected nerve was re-exposed and refreshed by removing two millimeters from both proximal and distal ends. The nerve gap was repaired by a six-millimeter nerve allograft from healthy donors. Fourteen weeks after surgical repair, the rats were euthanized using a gas. Then histomorphometric and electron microscopic evaluations were performed on the graft and distal nerve segments. Three animals from each group were excluded from the study because the graft had been detached. 
Fourteen weeks after the surgical nerve repair, the animals were euthanized. Five-millimeter samples were harvested from the graft and distal nerve segments. Samples were fixed with $2.5 \%$ glutaraldehyde and embedded in the resin. Semi-thin transverse sections ( $1 \mu \mathrm{m}$ thickness) obtained from resin blocks were stained with $1 \%$ toluidine blue and then examined by a light microscope [15]. The morphometric analysis was carried out by using ImageJ and Digimizer software. The mean nerve fiber density was quantified in four randomly chosen non-adjacent fields at 400x magnification, while the mean axonal cross-sectional area, myelinated nerve fiber diameter, axonal diameter, myelin thickness, and the mean surface area of intrafascicular space (the area between myelinated nerve fibers) was estimated in four fields at 1000x magnification (Fig. 1). The fiber diameter was calculated from the imaginary circle corresponding to the fiber area $(2 \times \sqrt{f i b e r}$ area/ $\pi)$ [16]. Since the default value of the unit area was $1000 \mu \mathrm{m} 2$, the net intrafascicular space "a" was calculated by subtracting the sum of the surface areas of myelinated fibers "b" from the unit area $(a=1000-b)$.

\section{Electron microscopic examination}

For electron microscopic analyses, $30-40 \mathrm{~nm}$ thin sections of the distal segments were

obtained from the above resin. These thin sections were stained with $2 \%$ uranyl acetate and $0.4 \%$ lead citrate and observed by the LEO 912AB transmission electron microscope (Zeiss). The electron micrographs were taken using the same microscope (Fig. 2). A grading system was used to determine the degree of myelin damage (Fig. 3). Grade zero represents normal morphology. Grade one represents separation in the myelin configuration. Grade two represents a disruption in myelin configuration. Grade three represents a honeycomb view of myelin, and grade four indicates collapsed myelin-forming ovoids [17].

\section{Statistical analysis}

Data were analyzed by IBM SPSS Statistics 25 software. The comparison of the groups was performed by using non-parametric independent-samples Kruskal-Wallis test for the graft and distal segments separately. If there was a statistically significant difference among groups in this test ( $P$-value $<0.05)$, the groups were compared in pairs using Mann-Whitney U non-parametric test. In this test, a significance level of 0.01 and a confidence level of $99 \%$ were considered to reduce the first type error ( $P$-value $<0.01$ was considered statistically significant) [15].

\section{Results}

\section{Histomorphometric analysis:}

The results of histomorphometric evaluation of the garft and distal nerve segment are shown in Table 1, 2 and 3 . There were statistically significant differences between sham (intact) and experimental groups for all morphometric indices $(P<0.01)$ (Table 1 and 2$)$. There was no statistically significant difference regarding mean fiber density between the citicoline group and the control group 1 , while mean fiber 
density was significantly higher in the atorvastatin and citicoline + atorvastatin distal segment compared to that of the control group $2(\mathrm{P}<0.01)$ (Table 2). Mean axonal cross-sectional area, myelinated fiber diameter, axonal diameter, and myelin thickness were significantly higher in the distal segment of citicoline, atorvastatin, and citicoline + atorvastatin compared to that of the control groups $(P<0.01)$ (Table 2). The distal segment of citicoline, atorvastatin, and citicoline + atorvastatin also showed a significantly smaller surface area of intrafascicular space than those of the control groups $(P<0.01)$. In the graft segment, there were no statistically significant differences in the above parameters among experimental groups (Table 1). The comparison of the effects of treatments of citicoline, atorvastatin, and citicoline + atorvastatin on the morphometric indices of the distal nerve segment showed that there is no significant difference between citicoline and atorvastatin groups in terms of morphometric indices (Table 3). Nevertheless, nerve morphometric indices in the citicoline group were slightly better than atorvastatin. On the other hand, although there was no significant difference in fiber density between the citicoline and citicoline + atorvastatin groups, the fiber density in the citicoline + atorvastatin group was significantly higher than the atorvastatin group $(P<0.01)$ (Table 3$)$. There were no significant differences between the three groups regarding fiber diameter, axon diameter, and fiber area. The surface area of the intrafascicular space in the citicoline + atorvastatin group was significantly lower than the atorvastatin group $(P<0.01)$. There were no significant differences in terms of intrafascicular surface area between the citicoline and citicoline + atorvastatin groups.

Insert tables 1, 2 and 3

\section{Ultrastructural Findings:}

The results of the electron micrograph evaluation of the distal nerve are shown in Fig. 2 and 3 . In the sham group, almost all fibers had a normal myelin sheath (zero degree of degradation). Only $4 \%$ of the fibers showed the first-degree degradation of myelin (vesicular myelin sheath), which is probably related to the delayed fixation.

In the citicoline group, $65 \%$ of the fibers in the distal nerve had normal myelin sheath.

Also, $15 \%$ of fibers had first-degree myelin destruction, $12 \%$ of fibers had second-degree myelin destruction, $4 \%$ of fibers had third-degree myelin destruction, and $4 \%$ of fibers had fourth-degree myelin destruction (Fig. 2 and 3).

In the atorvastatin group, $60 \%$ of the fibers in the distal nerve had normal myelin sheaths. $20 \%$ of fibers had first-degree myelin destruction, $8 \%$ of fibers had second-degree myelin destruction, $8 \%$ of fibers had third-degree myelin destruction, and $4 \%$ of fibers had fourth-degree myelin destruction (Fig. 2 and 3 ).

In the citicoline + atorvastatin group, $76 \%$ of fibers had normal myelin sheath. $12 \%$ of fibers showed firstdegree myelin degradation. $4 \%$ of fibers had second-degree myelin degradation. $4 \%$ of fibers had thirddegree myelin degradation, and $4 \%$ of fibers had fourth-degree myelin degradation (Fig. 2 and 3 ). 
In the control group 1, $12 \%$ of the fibers had a normal myelin sheath. $20 \%$ of the fibers showed firstdegree myelin degradation. $16 \%$ of the fibers had second-degree myelin degradation. $32 \%$ of the fibers had third-degree myelin degradation, and $20 \%$ of the fibers had fourth-degree myelin degradation (Fig. 2 and 3).

In the control group $2,11 \%$ of the fibers had a normal myelin sheath. $25 \%$ of the fibers had first-degree myelin degradation. $12 \%$ of the fibers had second-degree myelin degradation. $28 \%$ of the fibers had thirddegree myelin degradation, and $24 \%$ of the fibers had fourth-degree myelin degradation (Fig. 2 and 3 ).

\section{Discussion}

In this study, the effects of citicoline and atorvastatin on the structure, and ultrastructure of the distal segment of the injured nerve, were studied after nerve transection followed by one-month delayed nerve repair. The findings of this study showed that, however, there was no significant difference regarding mean fiber density between the citicoline group and the control group 1, mean fiber density was significantly higher in the distal segment of atorvastatin and citicoline + atorvastatin groups, compared to that of the control group 2. In addition, mean axonal cross-sectional area, myelinated fiber diameter, axonal diameter, and myelin thickness were significantly higher in the distal segment of citicoline, atorvastatin, and citicoline + atorvastatin, compared to that of the control groups. Since the comparison of grafts did not show a significant difference in terms of nerve morphometric indices, it seems that the difference between medication and control groups is due to differences in the axonal regeneration capacity of the distal nerve. Since the increase in fiber diameter occurs gradually during axonal outgrowth [19], the presence of large-diameter fibers in the distal nerve segment of the medication groups can indicate that the entry of axons into the distal nerve occurred earlier in these groups than the control groups. Likewise, it can be said that the small-diameter fibers in the control groups are probably new fibers that have entered the distal nerve segment lately. Prolonged denervation causes the endoneurial space to undergo structural changes and to be filled with collagen fibrils [20], which lead to fibrosis. The extraneural and intraneural fibrosis is the most important barrier to the regeneration of axons in the distal part of the nerve [21]. Therefore, the growth cone has to dissolve scar tissue by secreting enzymes [22], which leads to a delay in the entry of axons into the distal segment.

In the present study, the mean surface area of intrafascicular space (the area between myelinated fibers) in the distal nerve segment of the medication groups was significantly lower than that of the control groups. Since no significant difference in the fiber density was observed between the citicoline and control group 1, increased intrafascicular space (in the control group 1) could indicate fibrosis of the distal nerve $[19,23]$. On the other hand, the smaller mean surface area of intrafascicular space in the atorvastatin and citicoline + atorvastatin groups compared with control group 2 could be partly due to the higher fiber density in these groups compared to the control group 2.

According to previous reports, administration of citicoline (78, 80 and $293 \mathrm{mg} / \mathrm{kg}$ ) after the nerve injury accelerates the nerve regeneration in models of immediate nerve repair [6-9]. The positive effects of 
citicoline in these models are probably due to its metabolites, choline, cytidine, or both $[7,8]$. Moreover, administration of citicoline after PNI prevents the formation of scar tissue around the nerve and nerve edema [6, 9]. Likewise, administration of atorvastatin $(10 \mathrm{mg} / \mathrm{kg})$ before/ after nerve injury improves the morphological and functional indices of the injured nerve $[10,11]$.

In this study, the comparison of the effects of three medication treatments showed that there was no significant difference in the morphometric indices between citicoline and atorvastatin groups. Although in the citicoline + atorvastatin group, the fiber density and mean surface area of intrafascicular space were similar to the citicoline group, but this group had higher fiber density and smaller surface area of intrafascicular space than the atorvastatin group. The decrease in the mean surface area of intrafascicular space in the citicoline + atorvastatin group is probably due to the higher fiber density in this group compared to the atorvastatin group. In addition, myelin thickness in the citicoline + atorvastatin group was significantly higher than the citicoline and atorvastatin groups. On the other hand, fiber diameter, axon diameter, and axonal cross-sectional area were similar in all three medication treatments. Since the morphometric indices of the nerve (fiber density, myelin thickness, and surface area of intrafascicular space) in the citicoline + atorvastatin group were better than the two groups of citicoline and atorvastatin, it seems that the co-administration of citicoline, and atorvastatin, has a synergistic effect on improving morphometric indices of the nerve. One of the proposed mechanisms for this synergistic effect is the effect of atorvastatin on increasing the activity of the enzyme phosphocholine cytidylyltransferase [24], which is an enzyme that synthesizes intracellular CDP-choline (citicoline) [25]. Therefore, the atorvastatin co-administration may increase the synthesis of intracellular citicoline, which its effects can be added to that of injected citicoline. Also, both citicoline and atorvastatin have antiinflammatory, anti-apoptotic, and anti-oxidative effects, which can be exacerbated by the combination of two medications $[4,5]$.

The findings of the ultrastructural study of the nerve using TEM showed that in the medication groups, the majority of fibers in the distal nerve have a normal myelin sheath. Only a small percentage of the fibers in this group had degenerative myelin sheaths (with a low degree of degradation) that may be related to fibers that have not reached their target organ [26]. The healthy myelin sheath indicates the sufficient support of Schwann cells to the regenerating axons and the absence of fibrous tissue in the distal nerve segment and the muscle [3]. That various factors are involved in Schwann cell damage, such as excitotoxicity, oxidative stress, apoptosis, and inflammation [27, 28]. Recent studies have shown that citicoline reduces inflammation and ROS formation by inhibiting phospholipase A2 (PLA2) [29]. Inflammation plays a key role in fibrosis formation [30]. In addition, citicoline has anti-apoptotic effects and reduces glutamate excitotoxicity [27]. Choline, as a citicoline metabolite, is a precursor of acetylcholine [27]. Acetylcholine through its nicotinic receptor (nAChR) prevents muscle atrophy induced by denervation [31]. Likewise, atorvastatin reduces oxidative stress [32], apoptosis [32], inflammation [32], permeability of blood-nerve barrier [10], and inhibits activity of matrix metalloproteinase [10] after peripheral nerves injury. On the other hand, in the control group 1 (and also control group 2), however, the fiber density under the light microscope was similar to the citicoline group, but the examination by electron microscope showed that the majority of fibers in the control group have a myelin sheath with a 
high-degree of degradation. This difference indicates a need for ultrastructural studies of the nerve using electron microscopy. Nerve ultrastructural changes in the control groups could be due to distal nerve fibrosis, Schwann cell, and target muscle atrophy. 3 In this study, there was no significant difference regarding morphometric and ultrastructural indices of the nerve between control group 1 (saline) and 2 (vehicle of atorvastatin).

Since the start of medication administration was one month before the nerve grafting and the start of axonal regeneration, and also the lack of difference among grafts in terms of axonal regeneration quality, it can be concluded that the effects of medications are only related to maintaining the axonal regenerative capacity of the distal nerve.

\section{Conclusions}

Findings of this study show that in conditions where nerve repair is not possible (delay in reconstructive surgery), administration of citicoline, atorvastatin, or both by maintaining the structure of the distal segment of nerve, enhance the regeneration of axons and nerve repair after nerve grafting.

\section{Declarations}

\section{Acknowledgments}

This study were supported by a grant from Ferdowsi University of Mashhad (No. 3/46389), which is gratefully acknowledged.

\section{Ethics approval:}

The experimental protocol was approved by the National Committee for Ethics in Biomedical Research (approval ID: IR.UM.REC.1398.090).

\section{Consent for publication:}

Not applicable.

\section{Availability of data and materials:}

The data used and/or analyzed in the present study are available from the corresponding author upon reasonable request.

\section{Competing interests:}

The authors declare that they have no competing interests.

\section{Funding:}


This study were supported by a grant from Ferdowsi University of Mashhad (No. 3/46389).

\section{Author details:}

${ }^{1}$ Department of Biology, Faculty of Science, Ferdowsi University of Mashhad, Iran

\section{References}

1. Scheib J, Höke A. Advances in peripheral nerve regeneration. Nat Rev Neurol. 2013;9(12):668-76.

2. Dahlin LB, Wiberg M. Nerve injuries of the upper extremity and hand. EFORT Open Rev. 2017;2(5):158-70.

3. Jonsson S, Wiberg R, McGrath AM, Novikov LN, Wiberg M, Novikova LN, et al. Effect of delayed peripheral nerve repair on nerve regeneration, Schwann cell function and target muscle recovery. PLoS One. 2013;8(2):e56484.

4. Adibhatla RM, Hatcher JF. Citicoline mechanisms and clinical efficacy in cerebral ischemia. J Neurosci Res. 2002;70(2):133-9.

5. Barone E, Cenini G, Di Domenico F, Martin S, Sultana R, Mancuso C, et al. Long-term high-dose atorvastatin decreases brain oxidative and nitrosative stress in a preclinical model of Alzheimer disease: a novel mecha-nism of action. Pharmacol Res. 2011;63(3):172-80.

6. Özay R, Bekar A, Kocaeli H, Karlı N, Filiz G, Ulus IH. Citicoline improves functional recovery, promotes nerve regeneration, and reduces postoperative scarring after peripheral nerve surgery in rats. Surg Neurol. 2007;68(6):615-22.

7. Aslan E, Kocaeli H, Bekar A, Tolunay S, Ulus IH. CDP-choline and its endogenous metabolites, cytidine and choline, pro-mote the nerve regeneration and improve the functional recovery of injured rat sciatic nerves. Neurol Res. 2011;33(7):766-73.

8. Caner B, Kafa MI, Bekar A, Kurt MA, Karli N, Cansev M, et al. Intraperitoneal administration of CDPcholine or a combination of cytidine plus choline improves nerve regeneration and functional recovery in a rat model of sciatic nerve injury. Neurol Res. 2012;34(3):238-45.

9. Liu L, Nie Z, Han H, Song Q, Jia X, Lian T, et al. Role of Citicoline in promoting the repair of acute peripheral nerve injury in rat models. Neurosci Biomed Eng. 2016;4(4):237-40.

10. Pan HC, Yang DY, Ou YC, Ho SP, Cheng FC, Chen CJ. Neuroprotective effect of atorvastatin in an experimental model of nerve crush injury. Neurosurgery. 2010;67(2):376-88.

11. Cloutier FC, Rouleau DM, Hébert-Davies J, Beaumont PH, Beaumont E. Atorvastatin is beneficial for muscle reinnervation after complete sciatic nerve section in rats. J Plast Surg Hand Surg. 2013;47(6):446-50.

12. Kaplan T, Kafa IM, Cansev M, Bekar A, Karli N, Taskapilioglu MO, et al. Investigation of the dosedependency of citicoline effects on nerve regeneration and functional recovery in a rat model of sciatic nerve injury. Turk Neurosurg. 2014;24(1):54-62. 
13. Stenberg L, Stößel M, Ronchi G, Geuna S, Yin Y, Mommert S, et al. Regeneration of long-distance peripheral nerve defects after delayed reconstruction in healthy and diabetic rats is supported by immunomodulatory chitosan nerve guides. BMC Neurosci. 2017;18(1):53.

14. Citak MS, Cué JI, Peyton JC, Malangoni MA. The critical relationship of antibiotic dose and bacterial contamination in experimental infection. J Surg Res. 1992;52(2):127-30.

15. Dykstra MJ. Biological electron microscopy: theory, techniques, and troubleshooting. New York: Plenum Press; 1992.

16. Duval T, Saliani A, Nami H, Nanci A, Stikov N, Leblond H, et al. Axons morphometry in the human spinal cord. Neuroimage. 2019;185:119-28.

17. Sevuk L, Vayisoglu Y, Korlu S, Çömelekoğlu Ü, Arpacı RB, Aktaş S, et al. The effects of methylprednisolone and vitamin A on the healing of traumatic peripheral nerve paralysis. $\mathrm{J}$ Int Adv Otol. 2015;10(3):275-80.

18. Howell DC. Sampling distributions and hypothesis testing. In: Fundamental statistics for the behavioral sciences. 8th ed. CA: Cengage Learning; 2014. p. 167-70.

19. Xu C, Kou Y, Zhang P, Han N, Yin X, Deng J. et al. Electrical stimulation promotes regeneration of defective peripheral nerves after delayed repair intervals lasting under one month. PLoS One. 2014;9(9):e105045.

20. Ashley Z, Sutherland H, Lanmüller H, Russold MF, Unger E, Bijak M, et al. Atrophy, but not necrosis, in rabbit skeletal muscle denervated for periods up to one year. Am J Physiol Cell Physiol. 2007;292(1):C440-51.

21. Wang ML, Rivlin M, Graham JG, Beredjiklian PK. Peripheral nerve injury, scarring, and recovery. Connect Tissue Res. 2019;60(1):3-9.

22. Santiago-Medina M, Gregus KA, Nichol RH, O'Toole SM, Gomez TM. Regulation of ECM degradation and axon guidance by growth cone invadosomes. Development. 2015;142(3):486-96.

23. den Dunnen WF, van der Lei B, Schakenraad JM, Stokroos I, Blaauw E, Bartels H, et al. Poly(DLlactide-epsilon-caprolactone) nerve guides perform better than autologous nerve grafts. Microsurgery. 1996;17(7):348-57.

24. Verd JC, Peris C, Alegret M, Díaz C, Hernández G, Vázquez M, et al. Different effect of simvastatin and atorvastatin on key enzymes involved in VLDL synthesis and catabolism in high fat/cholesterol fed rabbits. Br J Pharmacol. 1999;127(6):1479-85.

25. Adibhatla RM, Hatcher JF, Dempsey RJ. Cytidine-5'-diphosphocholine affects CTP-phosphocholine cytidylyltransferase and Lyso-phosphatidylcholine after transient brain ischemia. J Neurosci Res. 2004;76(3):390-6.

26. Ikeda $\mathrm{M}, \mathrm{Oka} \mathrm{Y}$. The relationship between nerve conduction velocity and fiber morphology during peripheral nerve regeneration. Brain Behav. 2012;2(4):382-90.

27. Gandolfi S, Marchini G, Caporossi A, Scuderi G, Tomasso L, Brunoro A. Cytidine 5'-diphosphocholine (citicoline): Evidence for a neuroprotective role in glaucoma. Nutrients. 2020;12(3):793. 
28. Swiderski K, Azari MF, Profyris C, Petratos S. Molecular mechanisms in Schwann cell survival and death during peripheral nerve development, injury and disease. Neurotox Res. 2005;7(1-2):151-67.

29. De S, Trigueros MA, Kalyvas A, David S. Phospholipase A2 plays an important role in myelin breakdown and phagocytosis during Wallerian degeneration. Mol Cell Neurosci. 2003;24(3):753-65.

30. D'Ambrosi N, Apolloni S. Fibrotic Scar in Neurodegenerative Diseases. Front Immunol. 2020;11:1394.

31. Cisterna BA, Vargas AA, Puebla C, Fernández P, Escamilla R, Lagos CF, et al. Active acetylcholine receptors prevent the atrophy of skeletal muscles and favor reinnervation. Nat Commun. 2020;11:1073.

32. Pathak NN, Balaganur V, Lingaraju MC, Kant V, Latief N, More AM, et al. Atorvastatin attenuates neuropathic pain in rat neuropathy model by down-regulating oxidative damage at peripheral, spinal and supraspinal levels. Neurochem Int. 2014;68:1-9.

\section{Tables}

Table 1 Morphometric analysis of graft segments for each experimental group.Values are shown as median [minimum-maximum value]. 


\begin{tabular}{|c|c|c|c|c|c|c|}
\hline Groups & $\begin{array}{l}\text { Mean } \\
\text { fiber } \\
\text { density } \\
\text { (per } \\
5000 \\
\mu \mathrm{m} 2 \text { ) }\end{array}$ & $\begin{array}{l}\text { Mean fiber } \\
\text { area (per } 1000 \\
{\left.\mu m^{2}\right)}^{2}\end{array}$ & $\begin{array}{l}\text { Mean } \\
\text { axonal } \\
\text { diameter } \\
(\mu \mathrm{m})\end{array}$ & $\begin{array}{l}\text { Mean } \\
\text { myelinated } \\
\text { fiber } \\
\text { diameter } \\
(\mu \mathrm{m})\end{array}$ & $\begin{array}{l}\text { Myelin } \\
\text { thickness } \\
(\mu \mathrm{m})\end{array}$ & $\begin{array}{l}\text { Mean surface } \\
\text { area of } \\
\text { intrafascicular } \\
\text { space (per } 1000 \\
\mu^{2} \text { ) }\end{array}$ \\
\hline \multirow[t]{2}{*}{ Sham } & 13.5 & 307.81 & 12.49 & 19.80 & 3.6 & 300.14 \\
\hline & $\begin{array}{l}{[13-} \\
14.74]\end{array}$ & $\begin{array}{l}{[284.46-} \\
317.34]\end{array}$ & $\begin{array}{l}{[11.91-} \\
12.60]\end{array}$ & $\begin{array}{l}{[10.03-} \\
20.19]\end{array}$ & $\begin{array}{l}{[3.48-} \\
4.01]\end{array}$ & [242.06-355.34] \\
\hline \multirow{2}{*}{$\begin{array}{l}\text { Citicoline - } \\
\text { graft }\end{array}$} & $38 *$ & \multirow{2}{*}{$\begin{array}{l}62.74 *[48.74- \\
78.50]\end{array}$} & 6.51 * & 8.95 * & 1.22 * & 530 * \\
\hline & [35-42] & & $\begin{array}{l}{[5.30-} \\
7.20]\end{array}$ & [7.89-10] & $\begin{array}{l}{[1.21-} \\
1.40]\end{array}$ & {$[500-600.11]$} \\
\hline \multirow{2}{*}{$\begin{array}{l}\text { Atorvastatin- } \\
\text { graft }\end{array}$} & $36 *$ & \multirow{2}{*}{$\begin{array}{l}63.58 \text { * [48.49- } \\
80.07]\end{array}$} & 6.56 * & 9 * & 1.22 * & 541 * \\
\hline & [34-41] & & $\begin{array}{l}{[5.13-} \\
7.33]\end{array}$ & $\begin{array}{l}{[7.87-} \\
10.11]\end{array}$ & $\begin{array}{l}{[1.20-} \\
1.39]\end{array}$ & [511-589] \\
\hline \multirow{2}{*}{$\begin{array}{l}\text { Citicoline + } \\
\text { atorvastatin- } \\
\text { graft }\end{array}$} & 37 * & \multirow{2}{*}{$\begin{array}{l}63.02 *[45.58- \\
77.24]\end{array}$} & 6.51 * & 8.96 * & 1.23 * & 524 * \\
\hline & [33-39] & & $\begin{array}{l}{[5.12-} \\
7.13]\end{array}$ & [7.62-9.93] & $\begin{array}{l}{[1.22-} \\
1.40]\end{array}$ & [509-586] \\
\hline \multirow{2}{*}{$\begin{array}{l}\text { Control 1- } \\
\text { graft }\end{array}$} & $42 *$ & \multirow{2}{*}{$\begin{array}{l}71.74 *[59.92- \\
91.54]\end{array}$} & 6.96 * & 9.56 * & 1.30 * & \multirow{2}{*}{$\begin{array}{l}528.73 *[479.89 \\
616.89]\end{array}$} \\
\hline & [40-45] & & $\begin{array}{l}{[6.49-} \\
7.81]\end{array}$ & $\begin{array}{l}{[8.73-} \\
10.79]\end{array}$ & [1-1.49] & \\
\hline \multirow[t]{2}{*}{$\begin{array}{l}\text { Control 2- } \\
\text { graft }\end{array}$} & 41 * & \multirow[t]{2}{*}{$\begin{array}{l}67.89 *[42.34- \\
75.08]\end{array}$} & 6.80 * & 9.30 * & $1.25 *$ & 510 * \\
\hline & [33-45] & & $\begin{array}{l}{[6.60-} \\
7.50]\end{array}$ & [8.90-10.5] & $\begin{array}{l}{[1.12-} \\
1.5]\end{array}$ & [481-600] \\
\hline
\end{tabular}

* $\mathrm{P}<0.01$ as compared to sham group.

Table 2 Morphometric analysis of distal segments for each experimental group.Values are shown as median [minimum-maximum value]. 


\begin{tabular}{|c|c|c|c|c|c|c|}
\hline Groups & $\begin{array}{l}\text { Mean fiber } \\
\text { density } \\
\text { (per } 5000 \\
\mu \mathrm{m} 2)\end{array}$ & $\begin{array}{l}\text { Mean } \\
\text { fiber } \\
\text { area (per } \\
1000 \\
\left.{\mu \mathrm{m}^{2}}^{2}\right)\end{array}$ & $\begin{array}{l}\text { Mean } \\
\text { axonal } \\
\text { diameter } \\
(\mu \mathrm{m})\end{array}$ & $\begin{array}{l}\text { Mean } \\
\text { myelinated } \\
\text { fiber } \\
\text { diameter } \\
(\mu \mathrm{m})\end{array}$ & $\begin{array}{l}\text { Myelin } \\
\text { thickness } \\
(\mu \mathrm{m})\end{array}$ & $\begin{array}{l}\text { Mean surface } \\
\text { area of } \\
\text { intrafascicular } \\
\text { space (per } 1000 \\
\mu^{2} \text { ) }\end{array}$ \\
\hline \multirow[t]{2}{*}{ Sham } & 13.5 & 307.81 & 12.49 & 19.80 & 3.6 & 300.14 \\
\hline & [13-14.74] & $\begin{array}{l}\text { [284.46- } \\
317.34]\end{array}$ & $\begin{array}{l}{[11.91-} \\
12.60]\end{array}$ & $\begin{array}{l}{[10.03-} \\
20.19]\end{array}$ & $\begin{array}{l}{[3.48-} \\
4.01]\end{array}$ & [242.06-355.34] \\
\hline \multirow{2}{*}{$\begin{array}{l}\text { Citicoline - } \\
\text { distal }\end{array}$} & 28.50 * & $51.33 * \dagger$ & $5.60 *+$ & $8.08 *+$ & $1.24 *+$ & $602.46 *+$ \\
\hline & [20.50-35] & $\begin{array}{l}{[41.32-} \\
54.57]\end{array}$ & $\begin{array}{l}{[4.99-} \\
5.91]\end{array}$ & [7.25-8.33] & $\begin{array}{l}{[1.13-} \\
1.42]\end{array}$ & [524.87-654.45] \\
\hline \multirow{2}{*}{$\begin{array}{l}\text { Atorvastatin- } \\
\text { distal }\end{array}$} & $27 * \neq$ & $49.75 * \ddagger$ & $5.33 *$ * & $7.95 * \ddagger$ & 1.21 * & $604.76 * \ddagger$ \\
\hline & [23-31] & $\begin{array}{l}{[41.69-} \\
62.74]\end{array}$ & $\begin{array}{l}{[4.78-} \\
6.01]\end{array}$ & [7.28-8.93] & $\begin{array}{l}{[1.22-} \\
1.46]\end{array}$ & [601.71-663.78] \\
\hline \multirow{2}{*}{$\begin{array}{l}\text { Citicoline + } \\
\text { atorvastatin- } \\
\text { distal }\end{array}$} & $34 * \neq$ & $54.86 * \ddagger$ & $5.37 * \ddagger$ & $8.37 *$ * & $1.5 * \ddagger$ & $504.68 * \ddagger$ \\
\hline & $\begin{array}{l}{[32.40-} \\
37.25]\end{array}$ & $\begin{array}{l}{[49.98-} \\
62.74]\end{array}$ & $\begin{array}{l}{[4.76-} \\
5.83]\end{array}$ & [7.98-8.95] & [1.5-1.68] & [355.61-528.75] \\
\hline \multirow{2}{*}{$\begin{array}{l}\text { Control 1- } \\
\text { distal }\end{array}$} & 19 * & 27.38 * & 4.18 * & 5.90 * & 0.86 * & 869.55 * \\
\hline & $\begin{array}{l}{[17.98-} \\
24.55]\end{array}$ & $\begin{array}{l}{[25.36-} \\
28.04]\end{array}$ & $\begin{array}{l}{[3.88-} \\
4.19]\end{array}$ & [5.68-5.97] & $\begin{array}{l}{[0.86-} \\
0.95]\end{array}$ & [785.16-916.05] \\
\hline \multirow{2}{*}{$\begin{array}{l}\text { Control 2- } \\
\text { distal }\end{array}$} & $20 *$ & 26 * & 4.09 * & 5.79 * & $0.85 *$ & 862.36 * \\
\hline & [17-23] & $\begin{array}{l}{[17.39-} \\
35.07]\end{array}$ & $\begin{array}{l}{[4.04-} \\
4.14]\end{array}$ & [5.68-5.97] & $\begin{array}{l}{[0.81-} \\
0.95]\end{array}$ & [791-901] \\
\hline
\end{tabular}

*, $\dagger$ and $\ddagger \mathrm{P}<0.01$ as compared to sham, control group 1 and control group 2 respectively.

Table 3 The comparison of the effects of treatments of citicoline, atorvastatin, and citicoline + atorvastatin on the morphometric indices of the distal nerve segment. Values are shown as median [minimum-maximum value]. 


\begin{tabular}{|c|c|c|c|c|c|c|}
\hline Groups & $\begin{array}{l}\text { Mean fiber } \\
\text { density } \\
\text { (per } 5000 \\
\mu \mathrm{m} 2)\end{array}$ & $\begin{array}{l}\text { Mean } \\
\text { fiber } \\
\text { area (per } \\
1000 \\
{\left.\mu \mathrm{m}^{2}\right)}^{2}\end{array}$ & $\begin{array}{l}\text { Mean } \\
\text { axonal } \\
\text { diameter } \\
(\mu \mathrm{m})\end{array}$ & $\begin{array}{l}\text { Mean } \\
\text { myelinated } \\
\text { fiber } \\
\text { diameter } \\
(\mu \mathrm{m})\end{array}$ & $\begin{array}{l}\text { Myelin } \\
\text { thickness } \\
(\mu \mathrm{m})\end{array}$ & $\begin{array}{l}\text { Mean surface } \\
\text { area of } \\
\text { intrafascicular } \\
\text { space (per } 1000 \\
{\mu \mathrm{m}^{2} \text { ) }}^{\text {a }}\end{array}$ \\
\hline \multirow{2}{*}{$\begin{array}{l}\text { Citicoline - } \\
\text { distal }\end{array}$} & 28.50 * & $51.33 * \dagger$ & $5.60 *+$ & $8.08 *+$ & $1.24 * \dagger$ & $602.46 *+$ \\
\hline & [20.50-35] & $\begin{array}{l}{[41.32-} \\
54.57]\end{array}$ & $\begin{array}{l}{[4.99-} \\
5.91]\end{array}$ & [7.25-8.33] & $\begin{array}{l}{[1.13-} \\
1.42]\end{array}$ & [524.87-654.45] \\
\hline \multirow{2}{*}{$\begin{array}{l}\text { Atorvastatin- } \\
\text { distal }\end{array}$} & $27 * \ddagger$ & $49.75 * \ddagger$ & $5.33 * \ddagger$ & $7.95 * \ddagger$ & $1.21 * \ddagger$ & $604.76 * \ddagger$ \\
\hline & [23-31] & $\begin{array}{l}{[41.69-} \\
62.74]\end{array}$ & $\begin{array}{l}{[4.78-} \\
6.01]\end{array}$ & [7.28-8.93] & $\begin{array}{l}{[1.22-} \\
1.46]\end{array}$ & [601.71-663.78] \\
\hline \multirow{2}{*}{$\begin{array}{l}\text { Citicoline + } \\
\text { atorvastatin- } \\
\text { distal }\end{array}$} & $34 * \neq$ & $54.86 *$ * & $5.37 * \ddagger$ & $8.37 * \ddagger$ & $1.5^{*} \ddagger$ & $504.68 * \ddagger$ \\
\hline & $\begin{array}{l}{[32.40-} \\
37.25]\end{array}$ & $\begin{array}{l}\text { [49.98- } \\
62.74]\end{array}$ & $\begin{array}{l}{[4.76-} \\
5.83]\end{array}$ & [7.98-8.95] & [1.5-1.68] & [355.61-528.75] \\
\hline
\end{tabular}

* and $+\mathrm{P}<0.01$ as compared to citicoline and atorvastatin groups respectively.

\section{Figures}
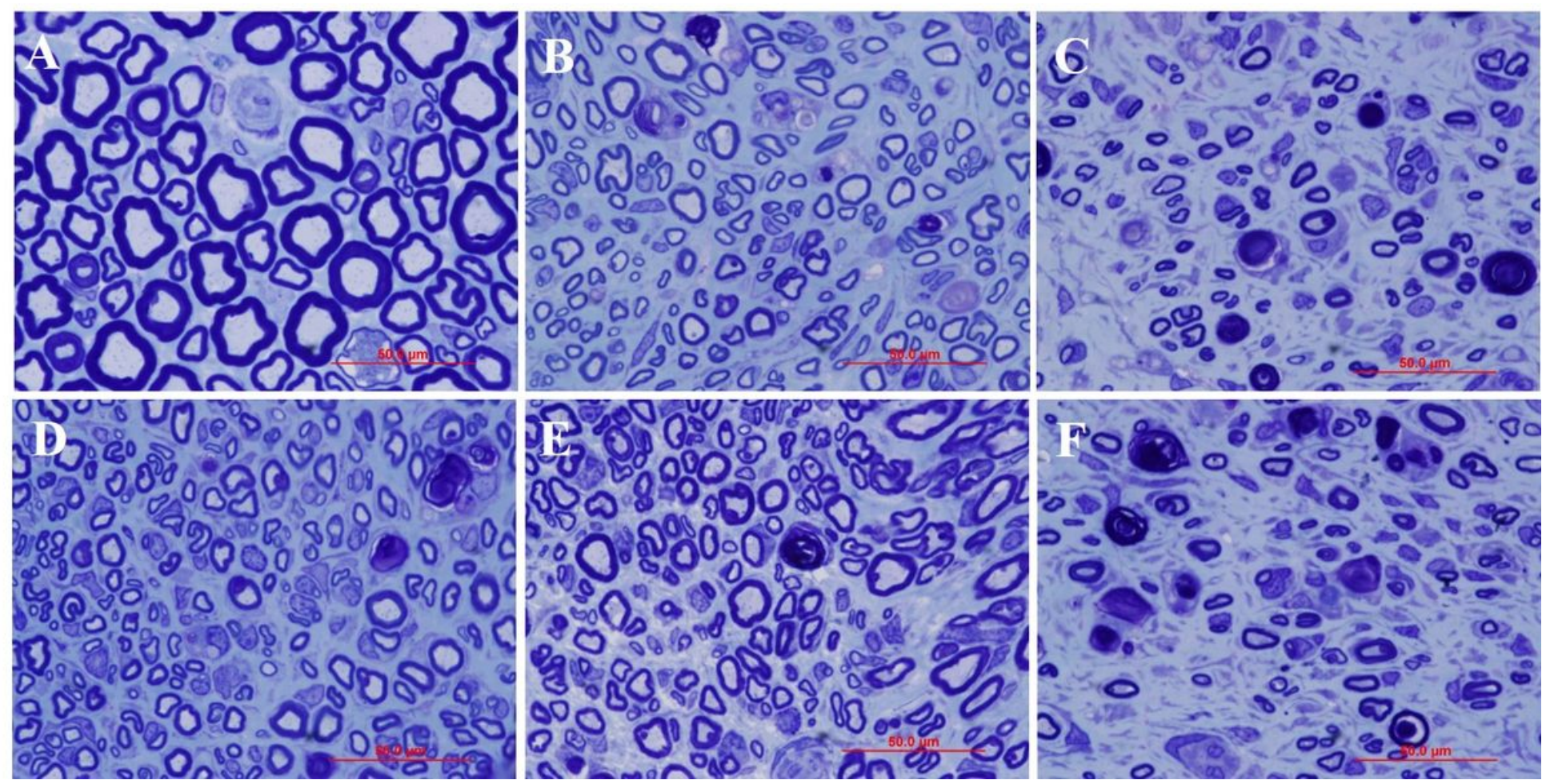

Figure 1 
Toluidine blue stained semithin cross-sections of distal segments of sciatic nerve 14 weeks after surgical nerve repair. (A) sham group, (B) distal segment of citicoline group, (C) Distal segment of atorvastatin group, (D) Distal segment of citicoline + atorvastatin group, (E) Distal segment of control group 1, (F) Distal segment of control group 2. Scale bar, $50 \mu \mathrm{m}$.
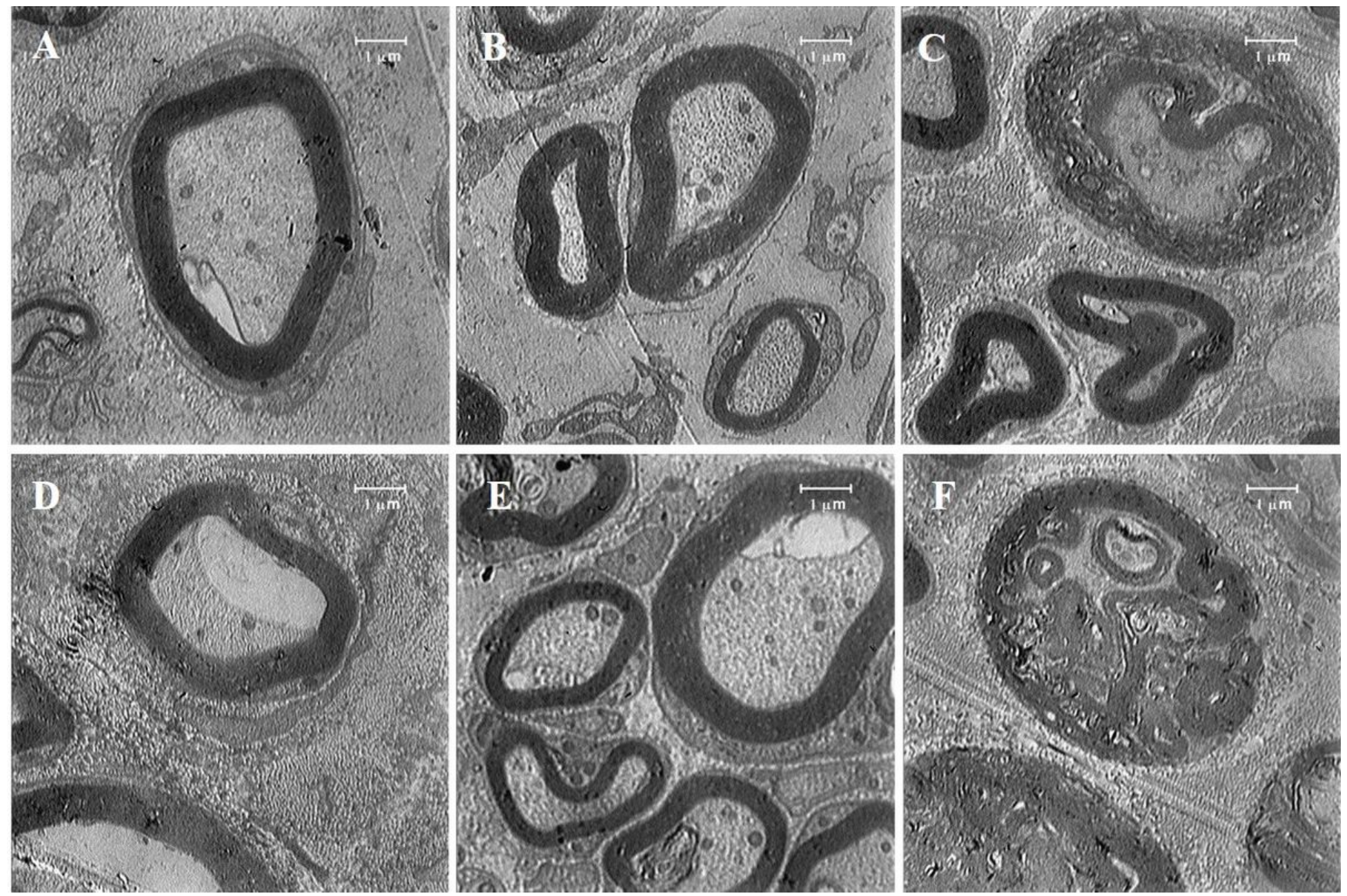

\section{Figure 2}

Electron micrographs of sciatic nerve distal segments after nerve transection and one-month delayed nerve repair. A: a myelinated nerve fiber with normal myelin sheath (white arrow) in the sham group. B: citicoline distal nerve segment shows large myelinated fibers with normal myelin sheaths (white arrow). C: atorvastatin distal nerve segment shows normal myelinated fibers (white arrow). D: citicoline + atorvastatin distal nerve segment shows normal myelinated fibers (white arrow). E: distal nerve segment of control group 1 shows a nerve fiber with high degree of myelin degeneration (white arrow). F: distal nerve segment of control group 2 shows a degenerating nerve fiber with infolded myelin loops (white arrow). Scale bar, $1 \mu \mathrm{m}$. 


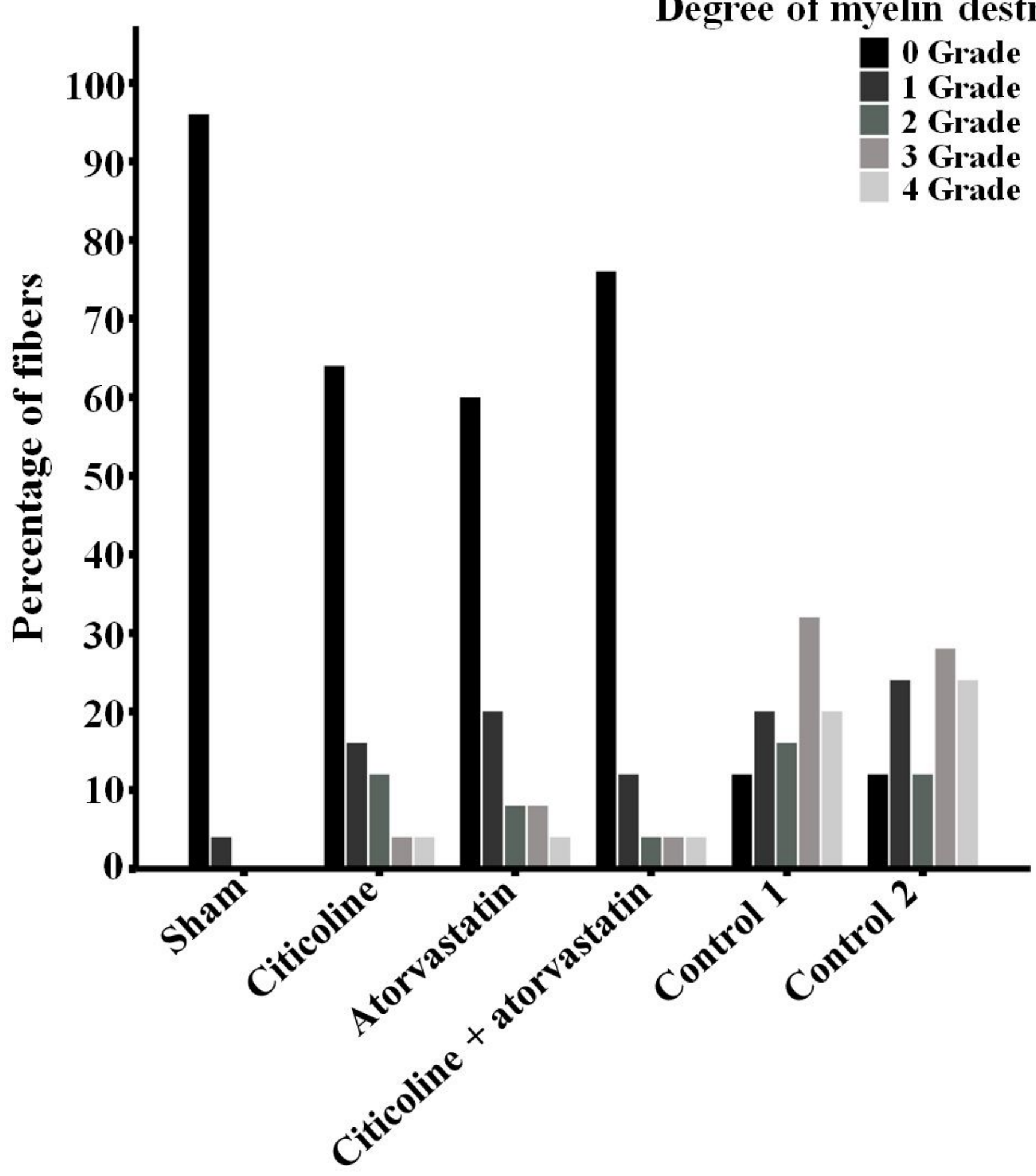

Figure 3

Distribution of myelinated nerve fibers with different degrees of myelin degradation in the distal segment of the sciatic nerve after evaluation of electron micrographs at the end of week 14. 